\title{
Qatar Community Mental Health Care: Achievements and Challenges
}

\section{Внебольничная психиатрическая помощь в Катаре: достижения и проблемы doi:10.17816/CP78}

\author{
(C) Mohamed Ali Ahmed, ${ }^{1}$ Suhaila Ali Ghuloum ${ }^{\mathbf{1 , 2}}$ \\ ${ }^{1}$ Mental Health Services, Hamad Medical Corporation, Qatar; \\ ${ }^{2}$ Weill Cornell Medicine, Doha, Qatar
}

\author{
(C) Мухамед Али Ахмед, ${ }^{1}$ Сухайла Али Гулум ${ }^{1,2}$ \\ 'Служба психиатрической помощи, Медицинская \\ корпорация Хамад, Катар; ${ }^{2}$ Медицинский колледж \\ Вейля Корнелла, Доха, Катар
}

\section{ABSTRACT}

Guided by international best practice and evidence-based medicine, the Qatar mental health service has undergone a major transformation in the last two decades, replacing the institution-based service with an accessible multidisciplinary community-based service.

In this paper, we provide a brief historical background to mental health services in Qatar, and the progress and development towards community-based mental health-care provision.

We also explore the challenges facing this new model of care in Qatar including social and cultural sensitivities, and the various solutions adopted to overcome these challenges.

We outline the comprehensive plans envisaged to further develop Qatar community mental health services, including the provision of accessible, integrated and multimodal mental health care within primary care settings.

\section{АННОТАЦИЯ}

Руководствуясь передовым международным опытом и достижениями доказательной медицины, служба психиатрической помощи в Катаре за последние два десятилетия прошла серьезные преобразования, в ходе которых стационарная модель заменялась доступной мультдисциплинарной внебольничной помощью.

В данной статье представлено краткое сообщение об истории служб охраны психического здоровья в Катаре, а также о прогрессе и развитии внебольничной психиатрической помощи.

Проанализированы проблемы, с которыми сталкивается новая модель оказания помощи в Катаре, включая социальные и культуральные особенности, а также различные решения, предпринимаемые для преодоления этих проблем.

Представлены современные планы по дальнейшему развитию внебольничной психиатрической службы в Катаре, включая предоставление доступной и комбинированной полипрофессиональной помощи в области охраны психического здоровья в условиях первичной медицинской сети.

Keywords: community mental health care; psychiatric services; Qatar; primary mental health care; assertive outreach mental health team

Ключевые слова: внебольничная психиатрическая помощь; службы психиатрической помощи; Катар; первичная психиатрическая помощь; группа по просвещению в области психического здоровья

\section{INTRODUCTION}

Qatar is a small country situated on a peninsula in the Arabian (Persian) Gulf; the only land border is with Saudi Arabia to the west. The country has witnessed significant economic and demographic growth over the past 20 years following the discovery and production of gas. As a result, Qatar is now considered to have the world's highest per capita gross domestic product (GDP). The 
population has grown rapidly from about 570,000 in 1999 to the latest estimate of 2.639 million in 2017 (World Bank). The majority of the population live in the capital city, Doha, with growing cities located primarily in the north and south. The vast majority of the population (85\%) are expatriates. ${ }^{1}$

Hamad Medical Corporation (HMC) is the main public provider of secondary and tertiary health care in the country, with a growing number of general and specialized hospitals under its umbrella, including Mental Health Services. Primary Health Care Corporation (PHCC) provides primary health-care services in 27 health centres distributed across the country.

Shortly after the first hospital opened in Qatar in 1948, psychiatry services were provided by general practitioners. ${ }^{2}$ Specialized mental health services were introduced in 1971 as outpatient clinics. ${ }^{3}$ Since then, significant progress has been made with the provision of a broad mix of inpatient, outpatient, community, and specialized mental health services. Electronic medical records were introduced within mental health clinics in late 2015, thus facilitating better data availability related to the services. For diagnostic coding purposes, ICD-10 is the main system used. However, many clinicians also use the DSM-5. The DSM diagnostic criteria have become more familiar to trainees as the residency and fellowship training programmes follow the American Accreditation Council of Graduate Medical Education (ACGME) standards for training.

\section{COMMUNITY MENTAL HEALTH SERVICES IN QATAR}

\section{Background}

Mental health services in the Arab world remain largely institution-based with resources focusing on inpatient hospital settings. Community mental health services vary considerably across the region and are mostly minimal. This is reflected in the scarcity of information in the published literature. Closer to Qatar, the Al-Ain province in the United Arab Emirates started its community team in 1994. The authors are not aware of any residential community mental health facility across the region. ${ }^{4}$

Until the start of a proper community outreach service in 1998, crisis-based home visits were arranged informally on an ad hoc basis, to the then very small population in Qatar. ${ }^{5}$ Shortly after this, a separate daycare service was established, run mainly by occupational therapists. The first dedicated Community Mental Health Team (CMHT) was established in 2001, providing day care, community outreach, and a limited crisis-intervention service. In a highly conservative and reserved society, with significant stigma associated with mental illness, and deep cultural and spiritual factors linked to its aetiology, the population had mixed attitudes towards community outreach services. In addition to this, the mental health workforce was recruited from different ethnic and training backgrounds, often with little psychiatric experience. Aspects of service delivery that are routine practice elsewhere, proved rather challenging. For example, the provision of community nurses dressed in non-uniform attire was seen as very unconventional, and using hospital vehicles with the hospital logo displayed was not welcomed by certain families fearing stigma. In response to these challenges, the preferences of service users were accommodated. Several training programmes were introduced to promote individualized care plans for patients and an interdisciplinary approach towards patient management was adopted.

In 2006, the first residential community-based facility was opened. Fifteen long-stay male patients with schizophrenia, who had been institutionalized within inpatient units, were moved to a large home. Despite scepticism from families and health-care staff alike, the move proved hugely successful. Patients were soon able to attend to their own activities of daily living, and administer their own medication. In addition, these patients required significantly lower doses of medication to stabilize their mental state, and they were able to reconnect with their families. The success of this initiative was instrumental in encouraging the expansion of the residential model to meet the service demands.

In 2013, Qatar's National Mental Health Strategy was launched. ${ }^{6}$ This was a five-year strategy with a vision to provide the right care, at the right time, and in the right place. It proposed an ambitious plan for providing services in a range of locations to ensure that people could access treatment in primary care and community settings, instead of a centralized mental health facility. ${ }^{5}$

\section{Current Services}

In early 2015, following the Mental Health Strategy recommendations, a better resourced community mental health team started providing services from a new community mental health facility located in the 
west of the capital city, Doha. This team provides a range of services including community outreach, psychiatric day-care programmes for male and female patients, residential rehabilitation, and community-based outpatient clinics. In 2019, the second community outreach team was established in the city of Al-Wakrah in the south of Qatar, and subsequently the catchment area was divided between the two teams.

The mental health community outreach service is provided by the two dedicated teams covering the whole country. The teams seek to provide effective multidisciplinary outreach intervention for individuals with severe and enduring mental illness who are very likely to disengage from services, stop their medication and relapse. This outreach service aims to ensure medication adherence, minimize relapse, and reduce the need for inpatient admissions. At present there are around 300 patients who are under the full mental health care of the community outreach service.

Moreover, the outreach teams provide home-based crisis intervention for patients with acute psychiatric presentations, and aim to manage such cases in home settings in order to avoid emergency room visits and hospital admissions. Patients and their families are provided with the phone numbers of community nurses to ensure easy access to care. Every patient is scheduled to be followed up regularly by an assigned psychiatrist and a community nurse (key worker) to ensure continuity of care.

Each outreach team is composed of experienced staff in mental health disciplines: three consultant psychiatrists, three trainee psychiatrists, a psychologist, eight community psychiatric nurses, a social worker, a dietician, and an occupational therapist. These teams are resourced with cars and mobile phones to be used for work duties.

Outreach teams receive referrals from the main psychiatric hospital's outpatient clinics and inpatient units, the emergency room in the general hospital and from primary health-care centres. All referrals are discussed in the weekly multidisciplinary team meetings where cases are assigned to psychiatrists and key workers (community nurses) in addition to other appropriate team members.

Home visits are then scheduled in coordination with patients and families, and comprehensive home assessments are conducted to identify all the psychological, physical, and social needs of patients. This enables the team to formulate a bio-psycho-social management plan and agree on follow-up arrangements with patients and families.

If these referrals are deemed to be urgent, crisis intervention will be provided. In some extremely urgent cases, the assistance of the ambulance service is required, and in rare cases of high risk, the assistance of the community police will be requested in agreement with the family.

Clinical progress of all cases is regularly discussed in the weekly multidisciplinary meetings, and management plans are reviewed. Key workers are responsible for scheduling regular home visits and for the provision of medication to patients.

The psychiatric day-care service is provided by a dedicated multidisciplinary team, bringing together all mental health specialties to support patients with chronic mental illness who need structure in their daily activities. Recovery objectives are implemented to rehabilitate patients and reintegrate them back into meaningful life activities such as family life, education, volunteering, and employment.

As part of respecting social and cultural norms in Qatar, there are separate day-care programmes in separate buildings for male and female patients, providing gender-appropriate activities. Day-care activities include group therapy sessions, outings, training on activities of daily living, medical assessments, and multidisciplinary interventions.

A day-care programme is commonly used for patients who require a more intense follow-up than can be provided in a regular outpatient clinic. In this sense, day care is commonly used as an alternative to inpatient admissions with some acutely unwell patients. At present, there is a total of 97 patients receiving full mental health care in the day-care programme: 58 males and 39 females.

The residential rehabilitation service includes supervised residential units for female patients with a total of 15 patients, and one supervised residential unit for five male patients. These units are for patients with severe and enduring mental illness who have spent long periods in acute inpatient settings and for whom 
discharge home is not an option for a variety of clinical or social reasons.

This residential service puts great emphasis on rehabilitation and recovery aspects such as family and community reintegration, training on activities of daily living including personal hygiene, money handling, shopping, cooking, and social skills.

Families are encouraged to visit their relatives on a regular basis, take them out for home visits and other outings, and engage in their treatment plan. Although very few patients are completely discharged home from these residential units, many spend an increasing amount of time at home during therapeutic home visits.

\section{Community-based outpatient clinics receive referrals} from 10 primary health-care centres located in the west of Doha. The remaining 27 centres in the country send referrals to the main outpatient clinics in the central psychiatric hospital. The most common diagnoses among referrals to these clinics are depression, anxiety and psychosomatic disorders.

The current caseload of this outpatient clinic is approximately 720 patients and is steadily increasing. These clinics are provided by the three community-based consultant psychiatrists in addition to the trainee doctors under consultant supervision.

\section{KEY PERFORMANCE INDICATORS (KPIS) FOR THE COMMUNITY MENTAL HEALTH SERVICES}

The following KPIs are used to measure the impact and quality of care provided within the community mental health service.

1. Reduction in admission rates and duration of hospital stay for the community caseload. Data collected within the service, not published, suggest a significant reduction in rates of inpatient admission and duration of hospital stay for individual patients after their engagement with the $\mathrm{CMHT}$. Follow-up by the CMHT has been a major contributor in facilitating earlier discharge from the acute inpatient settings.

2. Increase in service users' satisfaction. The CMHT receives regular feedback from patients and families to guide and inform service priorities and gauge service users' satisfaction. This feedback indicates that users' satisfaction has been steadily increasing.

\section{CHALLENGES FOR COMMUNITY MENTAL HEALTH SERVICES IN QATAR}

Large catchment area: This was a major challenge when only one outreach team covered the whole country. However, since the establishment of a second team in the south of Qatar, there has been more efficient caseload management utilizing a clearly demarcated catchment area-based distribution. Plans to start a new community outreach service in the north of Qatar are underway.

Stigma: The stigma of mental illness represents a major barrier to seeking and accepting appropriate mental health interventions. This subsequently leads to late presentations with acute psychiatric conditions through the emergency departments of HMC and eventually necessitating acute inpatient care. Stigma can render compliance with medications and clinic follow-up suboptimal.

Cases with speciall needs: Specialized services for people with comorbid mental illness and learning disability are still in their infancy in Qatar. The community team therefore provides care for an increasing number of such patients who require specialized expertise. The team collaborates with non-governmental organizations (NGOs) such as the Qatar Society for People with Special Needs, to assist in the management of these cases.

Co-morbid physical ill health: Patients with mental illness often have comorbid physical health problems, however, many of them show reluctance to seek medical care. The community outreach team regularly liaises with physicians and other health-care staff in the local general hospitals, primary health centres and other care providers to ensure mental and physical health-care aspects are provided in an integrated manner.

Mental health legislation: Whilst the mental health law was issued in November 2016, it has not yet been implemented, with many administrative procedures pending. Implementation of the law requires extensive training of relevant health-care providers in the country; this training is ongoing. The processes involved in initiating involuntary admission to the services, securing independent expert opinion, submitting relevant forms, and the appeal process, are still to be finalized. The authority in charge of supervising the whole process and 
ensuring that patients' rights are protected at all times (referred to in law as 'competent authority') has notyet been confirmed and the coordination with other authorities such as the police service, remains under consideration. Within the law, the presence of a community treatment order will facilitate the management of a certain category of patients once implementation begins, thus facilitating relapse-prevention management approaches.

\section{PLANS FOR DEVELOPING QATAR COMMUNITY MENTAL HEALTH SERVICES}

1. Establishing further community treatment hubs in other areas of the country will enable the sectorization of the catchment area and subsequent division of the current outreach caseload. The shortterm plan is for two hubs to open within the next couple of years, covering the north and central regions of the country.

2. The provision of specialized mental health clinics in primary care centres will provide more accessible services in a less stigmatized setting. An example of such a clinic has recently started in a primary care clinic located within the capital's education city, which hosts many educational facilities and campuses of international colleges and universities.

3. Establishing a dedicated crisis intervention and home treatment team will minimize the need for emergency room presentations and decrease the number of hospital admissions.

4. The provision of subspecialty community services such as a forensic psychiatry community team and a psychiatry of learning disability community team will facilitate the provision of specialised care that meets the needs of individual patients.

\section{PROVISION OF MENTAL HEALTH CARE WITHIN THE PRIMARY CARE SETTING}

Depression, anxiety and psychosomatic disorders are the most common mental illnesses seen in primary care centres in Qatar. ${ }^{6}$ Some of these cases are managed within primary care settings whilst others are referred to secondary mental health clinics.

The Primary Health Care Corporation (PHCC), the sole public provider of primary care in the country, has launched a comprehensive plan to optimize the provision of mental health care in primary care settings. This includes upskilling and training of general practitioners in mental health, provision of psychology services, ensuring the availability of most psychotropic medications within the PHCC pharmacy and the provision of secondary mental health clinics in primary care centres. The current focus is on the provision of mental health care for mild to moderate depression and anxiety disorders.

\section{Correspondence to:}

\section{Dr. Suhaila Ghuloum, MB BCh, FRCPsych}

sghuloum@hamad.qa

\section{For citation:}

Ahmed MA, Ghuloum SA. Qatar community mental health care: achievements and challenges. Consortium Psychiatricum. 2021;2(2):76-80. doi:10.17816/CP78

\section{References}

1. De Bel-Air F. Demography, Migration and Labour Market in Qatar. European University Institute and Gulf Research Centre; 2014.

2. Kronfol Z, Ghuloum S, Weber A. Country in focus: Qatar. Asian J Psychiatr. 2013;6(3):275-277. doi:10.1016/j.ajp.2013.02.004

3. El-Islam MF. Psychiatry in Qatar. Psychiatric Bulletin. 1995;19(12):779-781. doi:10.1192/pb.19.12.779

4. Saeed E, Wadoo O, Ouanes S. Community Mental Health Services. In: Haque A, Gilstrap LL, Ghuloum S, editors. Mental Health in Qatar: Challenges and Prospects. Cambridge Scholars Publishing; 2020: 364-386.

5. Ghuloum S, Ibrahim MA. Psychiatry in Qatar. Int Psychiatry. 2006;3(4):16-18. doi:10.1192/S1749367600004975

6. General Secretariat of the Supreme Council of Health. Qatar National Mental Health Strategy, Changing Minds, Changing Lives. The Supreme Council of Health; 2013. Accessed April 7, 2016. https://www.moph.gov.qa/healthstrategies/national-mentalhealth-strategy/ 